\title{
Science Education in a Museum: Enhancing Earth Sciences Literacy as a Way to Enhance Public Awareness of Geological Heritage
}

\author{
J. Reis • L. Póvoas • F. J. A. S. Barriga • C. Lopes • \\ V. F. Santos • B. Ribeiro • J. Cascalho • A. Pinto
}

Received: 30 November 2012 / Accepted: 6 March 2014 /Published online: 2 April 2014

(C) The European Association for Conservation of the Geological Heritage 2014

\begin{abstract}
Today, scientific literacy has become increasingly important as a hallmark of citizenship and as a way to facilitate many of life's daily decisions. Scientific literacy can be achieved through learning, a complex lifelong process that occurs both in school and out-of-school settings. As most adults only engage in formal education about science during compulsory schooling, all the learning that people go through in out-of-school settings and beyond compulsory schooling becomes extremely important toward the scientific literacy of the individual. The learning process in out-of-school settings requires interest from each person and can be facilitated by various agents, for example, museums. This is particularly true for Earth sciences as Geology topics are rarely taught within the science curricula during school. The Museu Nacional de História Natural e da Ciência provides realistic experiences that engage different publics into
\end{abstract}

J. Reis $(\bowtie) \cdot$ L. Póvoas $\cdot$ C. Lopes $\cdot$ V. F. Santos $・$ B. Ribeiro

J. Cascalho

Museu Nacional de História Natural e da Ciência, Universidade de

Lisboa, Rua da Escola Politécnica, nº56/58, 1250-102 Lisbon,

Portugal

e-mail: jleite@museus.ul.pt

J. Cascalho

Centro de Geologia, FCUL, Edifício C6 $3^{\circ}$ Piso, sala 6.3.57 Campo

Grande, 1749-016 Lisbon, Portugal

F. J. A. S. Barriga

CREMINER, Centro de Recursos Minerais, Mineralogia e

Cristalografia, LARSyS Lab Associado, FCUL, Edificio C6 Campo

Grande, 1749-016 Lisbon, Portugal

V. F. Santos

Centro de Investigação da Terra e do Espaço da UC - CITEUC, Av. Dr. Dias da Silva, 3000-134 Coimbra, Portugal

\section{A. Pinto}

(CREMINER/LARSyS, University of Lisbon, Faculty of Sciences, Geology Department, Edifício C6, Piso 4, Campo Grande,

1749-016 Lisboa, Portugal science and thus enhances the public science literacy. It is expected that by enhancing people's Earth sciences literacy, it will also enhance their awareness of geological heritage.

Keywords Science literacy · Public · Geological heritage · Museu Nacional de História Natural e da Ciência

\section{Introduction: Science Literacy and Geoscience Literacy}

Science is a key component of cultural literacy. Today, being scientifically literate is becoming more and more important not only because of all the technology that surrounds us but also, and mainly, because of all the environmental, health, and resources management issues that do affect us all to some extent. The acquisition of scientific knowledge and understanding of the process leading to the production of science and technology is essential to acquire the necessary skills for the exercise of citizenship and to contribute to life in a sustainably developed world (Reis et al. 2011).The expression "science literacy" seems to have appeared for the first time in the late 1950s. Several authors (e.g., Laugksch 2000; DeBoer 2000; Holbrook and Rannikmae 2009) trace it back to a Paul Hurd's paper from 1958 entitled Science Literacy: Its Meaning for American Schools. This concept has evolved with time, and despite all definitions that can be found through the literature (Laugksch 2000; DeBoer 2000; Holbrook and Rannikmae 2009), there is some consensus among authors in that there is more to science literacy than just knowledge. It is a multidimensional concept that involves knowledge, skills, and attitudes. Being scientifically literate implies not only being able to understand scientific concepts, such as facts, vocabulary, concepts, history, and philosophy, but also the ability to apply this knowledge in daily life situations, for example, conversations about science, questioning statements made by others about scientific matters, being able to answer questions, being able to decide on 
environmental and natural resources exploitation and management issues, and being able to decide about their own health and well-being (Burns et al. 2003; Hazen and Trefil 2009). Thus, the purpose of scientific literacy, rather than becoming very knowledgeable and being able to produce science, is being able to use science in our daily lives, particularly when making decisions that can affect ourselves, our families, and even the whole society. Science learning can be considered a lifelong endeavor that concerns attitudinal and behavioral change as well as changes in conceptual understanding (Falk et al. 2007).

The exponential growth of scientific knowledge and the increasing specialization of scientific disciplines have hindered knowledge's dissemination outside the scope of the communities of specialists who have produced it. Though is not difficult to find that knowledge in books or in the media, it can still be difficult to those who do not belong to the scientific community to access it. The fact that one can read, watch, or listen does not necessarily mean one can actually understand it. In fact, science has already reached such a level of complexity that if one does not possess a considerable background of scientific knowledge (which in itself might exclude much of the population), it can be hard to access and interpret that kind of information (Gil 1999). That being said, it is ironic that it might even not be enough to be a scientist to be scientifically literate. In fact, it is quite common that a scientist outside its one field of expertise is just like a layman, knowing as much or eventually even less than the average citizen (Hazen and Trefil 2009; Falk et al. 2007). So, as the Portuguese sociologist Boaventura Sousa Santos (2007) would say, both the scientist and the layman are ignorant, but the first is an expert (someone who knows much about something and not much about everything else). The second is a broad ignorant (someone that does not know much about anything but a little something about most things).

The way one achieves science literacy is through learning. Learning is a complex process that involves acquiring knowledge and skills (Falk 1997). It occurs both in formal domains (school) and nonformal and informal domains (outside school). This process is assimilative, dynamic, and cumulative, and it occurs all throughout a lifetime, and it can sometimes happen gradually or, in other times, instantaneously (Anderson et al. 2003; Rennie et al. 2003; Falk and Adelmar 2003). It involves constructing meanings by forming links between existing knowledge and new situations (UNESCO 1998). Learning consists of applying knowledge and skills that were acquired and refined in the past, through past experiences, to new experiences, occurring now, in some kind of physical context, which can be mediated by the actions of other individuals. This process is both and simultaneously cognitive and emotional, so learning is not just about reason (Falk 1997). Learning can be induced or facilitated by precursors which are something (exhibition, book, business, etc.) or someone (other individuals), that somehow induce a specific individual to become more interested in a subject such as, for example, science and technology (Rennie et al. 2003).
Within the domain of formal education, the case of Geology is peculiar. In secondary schooling (preuniversity schooling), Mathematics, Physics, Chemistry, and Biology are part of sciences curricula all over the world, and they are usually treated as individual subjects or at least in an even way. However, the same cannot be said about Geology: in most European countries and even worldwide, a few Geology topics are scattered through other subjects, but Geology usually does not exist as an independent subject (Fermeli, 2011; Orion 2007a). Portugal is a peculiar case: in the years preceding secondary schooling, Geology topics are also scattered through disciplines such as natural sciences and geography. However, in the 3 years of high school, Geology is supposed to be treated in equal terms as Biology. In the first 2 years, there is a subject named "Biology and Geology" (which not long ago used to be called "Earth and Life Sciences"), and in the last year, Geology can be chosen as an optional subject. But this is not a popular choice among most students, so some schools do not even provide that choice, arguing that either there are not enough students to form a class or that there is no teacher with proper qualifications.

It is pertinent to ask if Geology is important, and if so, why should it be included in the realm of science literacy?

Here are a few reasons:

- Geology as an Earth Science is an integrated science that brings together Biology, Chemistry, and Physics as they apply to the processes of the Earth, so learning about the Earth supports the development of problem-solving and critical-thinking skills (http://www.earthscienceliteracy. org/). It is also argued that Earth science should be part of the core of sciences school curricula not for the sake of preparing the future earth scientist but for the sake of preparing future scientifically literate citizens (King 2007), as it allows to develop certain thinking skills that are usually best developed within Earth sciences than in other scientific domains such as 3D thinking skills, development of deep time dimension, thinking simultaneous within time and space dimension, development of cyclic thinking, and development of system thinking (Orion 2007b).

- Biodiversity is largely dependent on geodiversity. New disciplines, i.e., Geobiodiversity and Geobiology, have already established themselves.

- Geodiversity is an essential part of nature, and it is deeply connected with the biosphere, so in order to understand nature, and indeed to understand our planet and protect its natural heritage (and even our cultural heritage), one necessarily needs to know about Geology.

- "If you cannot grow it, you have to mine it." Geodiversity has been providing all sorts of resources for the human kind; without which, modern societies would not exist. So, in order to properly exploit those resources in a 
sustainable way, one needs to know about Geology. Also, it is important that citizens at large are aware of, and understand, the arguments concerning this kind of issues.

- All populations are in some extent under the threat of some kind of natural hazard. In order to mitigate that risk, one needs to know about Geology.

- As for one more reason, geological knowledge provides us a broad and interesting perspective and understanding of the world around us both in spatial and time realms.

There has been an effort among the Earth sciences community to enhance society's awareness of the importance of what we do and our scientific domain: a couple of worldwide examples would be the National Science Foundation of the USA that has created the Earth Science Literacy Initiative (ESLI); the Geological Society of America (GSA) that published a document entitled GSA Position Statement-The Importance of Teaching Earth Science (http://www. earthscienceliteracy.org/); and the GEOschools project that is supported by the European Union's Lifelong Learning Programme, which brings together members of the geological science community from several institutions that aim to define a "Framework on geosciences literacy principles" for the general European citizens that should at least be applied, for the revision of compulsory school curricula for secondary schools for the participant countries (http://geoschools.geol.uoa.gr/).

The awareness of the importance of geological heritage has also been increasing. In reality, some acts of geological heritage conservation were carried as early as the nineteenth century. However, throughout history, nature conservation has been seen mainly as just "wildlife conservation" (Gray 2004). This has been changing, and today, a more holistic or even approach is becoming the new trend. In this context, since the late 80 s and early 90 s, several worldwide initiatives and projects concerning geoconservation began to appear, such as project GILGES, the creation of IUGS' Global Geosites Working Group, the creation of ProGEO, and the creation of both European and Global Geoparks Network (http://geoheritageiugs.mnhn.fr/index.php?catid=13\&blogid= 1; http://www.progeo.pt/progeo_pt.htm; http://www. europeangeoparks.org/?page_id=342; http://www. geoconservation.com/international/geoparks.htm; http://www. europeangeoparks.org/?page id=633; UNESCO, 1996).

The importance of formal education is undeniable. However, when considering lifelong education, one can realize that school, especially compulsory schooling, has its limitations. School does provide us with a very considerable and important baggage of knowledge that is difficult to learn outside a school setting (Falk et al. 2007), but mere personal experience tells us that each of us will only retain part of that knowledge (a very basic example of this is foreign languages: if one does not keep using it and practicing it, then it will probably be forgotten.) So, it is not how much we learn in school that matters, it is what we do with it and what we add to it through our lives that matters the most. And in fact, some surveys (e.g., Canavarro 2000; Falk et al. 2007) have revealed that nonformal and informal education seem to be (or at least are perceived to be) more important for science literacy than formal education.

\section{The Role of Museums: Earth Sciences at Museu Nacional de História Natural e da Ciência}

Museums are places for learning, education, and enjoyment as well as for study and collections. That is why they can be important precursors and enhancers of scientific literacy.

According to the International Council of Museums (ICOM) a museum is a " (...) non-profit, permanent institution in the service of society and its development, open to the public, which acquires, conserves, researches, communicates and exhibits the tangible and intangible heritage of humanity and its environment for the purposes of education, study and enjoyment." This definition was adopted during the 21st General Conference in Vienna, Austria, in 2007 (http://icom. museum/who-we-are/the-vision/museum-definition.html).

Museums are, therefore, much more than knowledgeproducing and collection-keeping institutions, they also have become knowledge-transmitting vehicles that aim at reaching all kinds of public. In fact, as agents of science dissemination, heritage guardians, and producers of knowledge, these institutions can act as links between the scientific community and society in a way that is hardly matched by other agents.

So, natural history museums (as well as other sciences museums) are very important as they are as follows:

- Institutions responsible for the preservation and management of collections.

- Institutions that have the potential to influence decisionmakers.

- Places for science education and scientific dissemination.

- Places that provide enjoyment and entertainment.

- Places that are able to connect scientific community with society.

This museum, Museu Nacional de História Natural e da Ciência, has inherited (and is continuing) a long tradition of scientific research, collections management, and scientific education (nonformal and informal settings) from its predecessor Museu Nacional de História Natural (MNHN).

For geological heritage, this museum has a very active role in geoconservation and it is undeniably one of the pioneers in this field in Portugal. In 1989, the Associção Portuguesa de Geólogos (APG) promoted a seminar in Aveiro Geologia e Ambiente (Geology and Environment). One of the main 
conclusions was that action was urgently needed with regard to geological heritage, and so a report was compiled with the three following goals:

1. To assemble the information available that was spread across the Portuguese Geological Survey (at the time called IGM - Institute of Geology and Mining) and several universities.

2. To create a proper inventory regarding geological heritage sites.

3. To create criteria to properly classify features and sites related to this kind of heritage.

In the original report, a total of 64 sites were listed, and afterwards, in 1990, APG, IGM, and MNHN joined together for the Project PAGE - Geological heritage with exceptional interest in Continental Portugal. Though it had limited results, this project was one of the first initiatives of this kind in Portugal.

The museum was also involved in one of the main projects concerning geological heritage which was the establishment of the Portuguese frameworks with international relevance (Galopim de Carvalho 1999; Brilha et al. 2005; Brilha 2005).

In 1993, the category of "Natural Monument" was created through the Decree 19/93 of 23 January 1993. Although it does not specifically concern geological heritage, it does allow the classification of sites of geological interest. Subsequently, five geosites with dinosaur tracks that had been proposed by MNHN received the Natural Monument official classification: one in 1996-Pedreira do Galinha, which is considered one of the best examples of geoconservation in Portugal (Brilha 2005, 2006) and four others in 1997-Pego Longo (Carenque, Sintra), Pedra da Mua, Avelino, and Lagosteiros (Sesimbra). Some of these are integrated into natural parks (Galopim de Carvalho 1994, 1999, 2004; Galopim de Carvalho and Santos 1992, 1994; Galopim de Carvalho et al. 1998; Relvas et al. 2005; Santos et al. 2008a, 2008b, 2010a and 2012).

This museum has been working together with several municipalities, such as Lisbon, Sesimbra, Sintra, Setúbal, Batalha, Grândola and Viseu, creating protocols, helping with the development of relevant geosites, or, in the very least, acting as a scientific consultant. The best example is probably Lisbon, where a collaboration of several public bodies (this museum, LNEG-National Laboratory of Energy and Geology - and the Faculty of Sciences of the University of Lisbon) allowed the identification of 19 outcrops across Lisbon city that were classified by the Lisbon Municipal Assembly and integrated as Nature Exo-Museums (in relation to the natural history museum) and afterwards became included in municipal planning instruments such as the municipal master plan. There is an extensive bibliography regarding these geosites and also institutions in those municipalities that benefited from partnerships with the museum (e.g., Galopim de Carvalho 1999, 2004; Galopim de Carvalho et al. 2012; Pinto et al. 2011; Póvoas et al. 2002; Relvas et al. 2012; Santos et al. 2008a, 2008b and 2010a, 2010b; and Tinoco et al. 2002). These partnerships have been proven to be worthwhile as Grândola and Sesimbra were awarded with 2013 ProGEO's Geoconservation Awards (Brilha 2008). The municipality of Grândola was the winner, with the initiative "Mining village of Lousal: an example of success in the rehabilitation of the geomining heritage in the Iberian Pyrite Belt" and Sesimbra received an honorable mention for the initiative "Geocircuit of Sesimbra" (http://www.progeo.pt/progeo_pt.htm).

In the last 20 years, the museum's education offer concerning Geology has been focused around two main themes: mineralogy and dinosaurs. The first theme is a traditional and classic geological subject and also because minerals are a major geological resource that provides raw materials for virtually any object we use in our daily lives - and their exploration and exploitation are crucial to the economy, the society, and the environment. As for the second theme, dinosaur paleontology, besides being one of the subjects of the scientific research of MNHN, it can be used as a strategy to attract the public not only to this topic (dinosaur paleontology) but also to several other topics in Earth sciences. This is possible as dinosaurs are part of the imaginative realm of both adults and children (Gould 1991; Gould 1995; Lopes and Póvoas 2000; Póvoas et al. 2010). They represent a kind of archetypal fascination as they are big, fierce, and extinct, which means that they are alluringly scary and yet quite safe, and besides, for the last few decades, they have been the subject of huge marketing campaigns and commercialization and have been used in cinema and television-leading to even more marketing and commercialization, especially after the release of the film Jurassic Park (Gould 1995). This film (along with the rest of the series) remains a main reference among the general public - although among the youngest members of the public other TV series may be a more important reference.

When designing any sort of activity (indoors, outdoors, exhibition, or in a teaching laboratory), it is important to try and improve public knowledge and increase their interest in Geology and also to enhance their awareness of the importance of Geology as a science, of geodiversity as part of nature and as a resource provider, and of geological heritage as part of natural and cultural heritage. This is true for this museum as well as other similar types of museums elsewhere-hence, there is usually a clear intention to go beyond providing a mere hands-on interactive experience. The aim is to provide experiences that reproduce, as much as possible, the successive steps used in scientific methodologies, using whenever possible instruments used in scientific research (Póvoas et al. 2010). In all these activities, the museum seeks to provide knowledge (either of the results of its own scientific research 
or from others) as well as to explain the types of methodologies used by scientists. This approach is completely consistent with the concept of science literacy as discussed above.

The museum staff that engage with the public when performing educational programs report that the public seem to enjoy engaging in hands-on activities. This view agrees with a recent poll concerning the public visiting this museum's Earth sciences exhibitions: $18.67 \%$ prefer hands-on exhibitions and $65.67 \%$ prefer exhibitions with a mixed approach (combination of "classic" and hands-on) (Leite 2009; Reis et al. 2008, 2010). As for the after effects of the museum visits, almost half of the respondents $(46.67 \%)$ stated that they had increased their interest in Geology and almost all of them $(92.67 \%)$ stated that they had increased their geological knowledge (more precisely, $24 \%$ stated that their geological knowledge was enhanced a little, $50.67 \%$ stated that it fairly increased, and $5 \%$ stated that it increased a lot; only $5 \%$ stated that it did not enhance at all). Statistical data has also verified that there is a positive correlation between having a previous interest in Geology and increasing knowledge and between increasing knowledge and increasing interest in Geology.

But in spite of the positive correlation (the Pearson correlation are, respectively, 0.223 and 0.367 ), these relationships are not necessarily straightforward: people with no interest or a very low interest in Geology did not significantly change their opinion, the same is true for people who already had a very high interest in Geology, so the people whose interest increased were the respondents that were initially fairly to highly interested in Geology. As for learning, the respondents with a high interest in Geology learned more than the ones with a very high interest. Finally, it also happens that it was not the ones who learned the most that were the ones who increased their interest more, and those who learned significantly increased their interest more than the ones who learned a lot (Leite 2009; Reis et al. 2008, 2010). It is easy to understand that it is difficult to enhance the interest of someone that is already very interested or the knowledge of someone who is already very knowledgeable. Being interested is definitely a good motivation for learning, and a learning opportunity might be the beginning of a new or renewed interest.

However, most people that come to visit museums are not necessarily aiming to learn something but rather to enjoy themselves (Falk and Dierking 2000; Falk and Aldemar 2003), so within an informal education setting, it is very important to be able to conciliate learning and leisure without one overshadowing the other. It is important to adjust and adapt to the different publics one is dealing with. It is expected that a school public will be more concerned with learning (at least the teachers) and a general public will probably be more prone to spending leisure time (with collateral learning effects). However, when spending some time observing the public in exhibitions, we witnessed a whole range of behaviors in all kinds of public: for example, we saw school groups pass through exhibitions without paying any attention to them, in contrast to students who came to the museum by their own to collect data and/or to take photos for some project. As for the general public, it is possible to find people who read every single panel, write lots of notes, or take many photos and people who seem to be crossing the room and not necessarily seeing the exhibition in it. It is also pretty common that the adults in family groups seem to bring their children so that they can learn something, using the visit to the museum as a learning opportunity. Also, when focusing on children, we realize that some are genuinely interested in the exhibitions, and it would not be farfetched to assume that they were the ones who asked to come to the museum and the ones who set the rhythm and pull along their adult companions. However, the opposite may also happen and some children are the ones who have to be pulled along as it seems that they only came because, as children, they could not impose their own will not to come along.

For those dealing with people from inside and outside scientific communities on a regular basis, it becomes clear that there is more required than just attending school in order to become scientifically literate. There is only so much one can learn from formal education. That is why museums are so important as contributors to lifelong education. This is particularly true when it comes to geosciences because, quite often, they are only superficially addressed in the curricula of compulsory schooling - as a result, without nonformal and informal education, many people would lack knowledge of the geosciences.

\section{Final Comment}

In the realm of geoconservation, museums can act on two different fronts: they can act directly at all stages of a geoconservation process, because they have the knowledge to do so and they can also act indirectly, just by performing their social and educational mission, connecting with people in order to make them aware of the importance of the geological heritage, even before any sites are actually classified. It is hard to put forward effective geoconservation measures if people do not care about what it is being protected. We believe that there is a very strong connection between being scientifically literate in Earth sciences and being aware of the importance of geological heritage. Indeed, if one has a good level of Earth science literacy, one should also be aware of the importance of geological heritage; hence, because of their role in contributing to increase society's Earth science literacy, museums make an important contribution to the conservation of geological heritage. 


\section{References}

Anderson D, Lucas KB, Ginns IS (2003) Theoretical perspectives on learning in an informal setting. J Res Sci Teach 40:177-199

Brilha J (2005) - Património Geológico e Geoconservação: A Conservação da Natureza na sua vertente geológica. Palimage Editores, Braga. 190 pp

Brilha J (2006) Proposta metodológica para uma estratégia de geoconservação. Livro de resumos do VII Congresso Nacional de Geologia III:925-927

Brilha J (2008) - Geoconservation Awards: a way to promote geological heritage in Portugal. Proc. 5th International Symposium ProGEO on the Conservation of the Geological Heritage, Rab, Croatia, 13-14

Brilha J, Andrade C, Azerêdo A, Barriga FJAS, Cachão M, Couto H, Cunha PP, Crispim JA, Dantas P, Duarte LV, Freitas MC, Granja HM, Henriques MH, Henriques P, Lopes L, Madeira J, Matos JMX, Noronha F, Pais J, Piçarra J, Ramalho MM, Relvas JMRS, Ribeiro A, Santos A, Santos VF, Terrinha P (2005) Definition of the Portuguese frameworks with international relevance as an input for the European geological heritage characterization. Episodes 28(3): $177-186$

Burns TW, O'Conner DJ, Stocklmayer SM (2003) Science communication: a contemporary definition. Public Underst Sci 12:183-202

Canavarro JM (2000) O que se pensa sobre a ciência. 1st Edition Quarteto

DeBoer GE (2000) Scientific literacy: another look at its historical and contemporary meanings and its relationship to science education reform. J Res Sci Teach 37:582-601

Falk JH (1997) Testing museum exhibition design assumption: effect on explicit labeling of exhibit clusters on visitor concept development. Sci Educ 81:679-687

Falk JH, Adelmar LM (2003) Investigating the impact of prior knowledge and interest on aquarium visitor learning. J Res Sci Teach 40:163176

Falk JH, Dierking LD, (2000). Learning from museums: visitor experiences and the making of meaning. Walnut Creek

Falk JH, Storksdieck M, Dierking LD (2007) Investigating public interest and understanding: evidence for the importance of free-choice learning. Public Underst Sci 16:455-469

Fermelli G (2011) Interest research in secondary schools on geosciences concepts. In Conferência GEOescolas: novas práticas no ensino das Geociências. pp 52-53 Geoparque Naturtejo, Idanha-a-Nova

Galopim de Carvalho AM (1994) - Dinossáurios e a batalha de Carenque. Editorial Notícias, Lisboa, $291 \mathrm{pp}$

Galopim de Carvalho AM, Santos VF, Moutinho M (1998) - Musealização das jazidas portuguesas com pegadas de dinossáurios. Certezas e perspectivas. In: A.M. Galopim de Carvalho, A.M. Andrade, V.F. Santos, J. Cascalho, R. Taborda \& C.M. da Silva (Eds.), Abstracts of 1st International Meeting on Dinosaur Paleobiology (Museology Program for the Portuguese Dinosaur Tracksites), Fundação Calouste Gulbenkian, Lisboa, Portugal, 26-29 de Maio de 1998, pp. 123-143

Galopim de Carvalho A.M.; (1999) Geomonumentos Uma reflexão sobre a sua caracterização e enquadramento num projecto nacional de defesa e valorização do Património Natural. Liga de amigos de Coimbra

Galopim de Carvalho A.M.; (2004) - Museu Mineralógico e Geológico Investigação e Museologia (1993 - 2003) 106 pp

Galopim de Carvalho AM, Santos VF (1992) - Sesimbra, um pólo importante para o conhecimento da história dos dinossáurios em Portugal. Câmara Municipal de Sesimbra. Sesimbra Cult 2:6-9

Galopim de Carvalho AM, Santos VF (1994) - Há dinossáurios na Serra d'Aire. Forum Ambiente 9:28-32

Galopim de Carvalho AM; Barriga FJAS; Carvalho RG (2012) O quartzo na Ciência, na tecnologia e na arte. Museu do Quartzo-Câmara Municipal de Viseu
Gil F (1999) A ciência tal qual se faz e o problema da objectividade. In A ciência tal qual se faz, Colecção Humanismo e Ciência 1st edn, Edições Sá da Costa, pp 9-29

Gould SJ (1991) A Feira dos Dinossáurios In A Feira dos Dinossauros 1st ed, pp. 86-97. Publicações Europa-América

Gould SJ (1995) Dinomania In Dinosaur in a haystack 1st edn, pp.221237 Harmony Books

Gray M (2004) Geodiversity: valuing and conserving abiotic nature. Wiley, Chichester

Hazen RM, Trefil J (2009) Science matters achieving scientific literacy 2nd Edition, Anchor Books

Holbrook J, Rannikmae M (2009) The meaning of scientific literacy. Int J Environ Sci Educ 40:275-88

King C (2007) What earth science might form the core of a new earth/ environmental science GCSE? Sch Sci Rev 89:71-7

Laugksch RC (2000) Scientific literacy: a conceptual overview. Sci Educ 84:77-94

Leite J (2009) Contributo do Museu Nacional de História Natural para a divulgação do património geológico: caracterização do público do Departamento de Mineralogia e Geologia. Master thesis, Universidade do Minho

Lopes C, Povoas L (2000) Dinossáurios Regressam em Lisboa - Análise de um Processo de Comunicação: - I Colóquio Luso-Brasileiro de Ciência, Tecnologia e Sociedade: A Comunicação Pública da Ciência, Montemor-o-Novo, pp.177-186

Orion N (2007a) A holistic approach for science education for all. Eurasia J Math Sci Technol Educ 2007 3(2):111-118

Orion N (2007b) The Israeli Earth science curriculum: goals, objectives and syllabus. personal communication. In King C (2007) What earth science might form the core of a new earth/environmental science GCSE? School Science Review 89:71-7

Pinto C, Vicente J, Pinto MM, Espirito Santo G, Muñoz M, Moitinho I (2011) Inventory dissemination and preservation of the geological heritage in urban areas - Lisbon city case study. Geo J Tour Geosites no2 8:263-271

Póvoas L, Relvas JMRS, Lopes C, Barriga FJAS (2002) Projecto museológico para as minas do Lousal: proposta de representação da geologia. Actas Congresso Internacional do Património Geológico e Mineiro. IGM/SEDPGYM/IPB, Beja

Póvoas L, Lopes C, Dantas P, Malafaia, E, Barriga FJAS. (2010) A exposição "Allosaurus: um dinossáurio, dois continentes?"Divulgar procedimentos científicos para promover literacia científica. VIII Congresso Nacional de Geologia (Universidade do Minho, Braga, 12-14 Julho 2010) e-Terra, 15 (51), http://e-terra. geopor.pt

Reis J, Brilha J, Barriga F, Lopes C, Póvoas L (2008) The contribution of natural history museums to raise public awareness of earth heritage. In 5th International ProGeo Symposium on Conservation of the Geological Heritage and ProGeo Working Group 1 Annual Meeting 1st - 5 October 2008 Rab Island, Croatia pp67-68

Reis J, Brilha J, Barriga F, Lopes C, and Povoas L (2010) O Museu Nacional de História Natural como promotor do Património Geológico: caracterização preliminar dos visitantes do Departamento de Mineralogia e Geologia. In Colecções e Museus de Geologia: Missão e Gestão. Brandão JM, Callapez P, Mateus O, and Castro P (ed.), pp. 369-76. Museu Mineralógico e Geológico da Universidade de Coimbra (MMGUC) Centro de Estudos de História e filosofia da Ciência (CEHFCi), Coimbra.

Reis J, Póvoas L, Ribeiro B (2011) Educação não formal no MNHN: o método como contributo para a Geoliteracia. In Conferência GEOescolas: novas práticas no ensino das Geociências. pp 59-60 Geoparque Naturtejo, Idanha-a-Nova

Relvas J, Póvoas L, Costa T, Matos J,Varela T, Lopes C, Barriga F (2005) - Project "Underground Visit to the Lousal Mine": rehabilitation of a closed mine in the Iberian Pyrite Belt towards sustainable development and preservation of mining heritage". IV International 
Symposium ProGEO on the Conservation of the Geological Heritage. Braga

Relvas JMRS, Pinto AMM, Matos JMX (2012) Lousal, Portugal: a successful example of rehabilitation of a closed mine in the Iberian Pyrite Belt. Soc Geol Appl Mineral Depos; SGA News 31:6-1

Rennie LJ, Feher E, Dierking LD, Falk JH (2003) Toward an agenda for advancing research on science learning in out-of-school settings. J Res Sci Teach 40:112-120

Santos VF, Rodrigues LA, Alho JM (2008a) - Middle Jurassic dinosaur track sites from Portugal: where science meets natural heritage. In: A. Uchman (Ed.), Abstract Book of The Second International Congress on Ichnology, Cracow, Poland, August 29-September 8, 2008, pp. 113-114.

Santos VF, Silva CM, Rodrigues LA (2008b) Dinosaur track sites from Portugal: scientific and cultural significance. Oryctos 8:77-88

Santos VF, Barriga FJAS, Galopim de Carvalho AM, Mergulhão LM, Monteiro C, Silveira SC, Fernandes MJ, Alho JM, Coelho R (2010a) - Dinosaur track sites from Portugal and its significance as natural heritage. In: V. Mügge-Bartolovic, H.-G. Röhling \& V. Wrede (Eds.), Abstract Book of the 6th International Symposium on Conservation of Geological Heritage, Hagen, Germany, 29 May - 2 June, 2010, p. 125

Santos VF, Barriga FJAS, Galopim de Carvalho AM, Mergulhão LM, Monteiro C, Silveira SC, Fernandes MJ, Alho JM, Coelho R (2010b) - Seguindo os passos dos dinossáurios do Mesozóico Português: valor excepcional de jazidas icnológicas a preservar. In: A. Santos, E. Mayoral, G. Meléndez, C.M. da Silva \& M. Cachão (Eds.), Livro de Resumos do III Congresso Ibérico de Paleontologia / XXVI Jornadas de la Sociedad Española de Paleontología, Lisboa, Portugal, 7 - 10 de Julho de 2010. Publicaciones del Seminário de Paleontologia de Zaragoza (SEPAZ), 9: 37-39

Santos VF, Callapez PM, Pinto JS (2012) - Reflexões sobre uma Aula de campo em torno de pegadas de dinossáurios no Monumento Natural do Cabo Mondego. I Congresso Internacional "GeoCiências na CPLP". Universidade de Coimbra. 12 a 19 de maio de 2012. p. 282

Sousa Santos, Boaventura (2007) Um Discurso sobre as Ciências. 15th(ed)Edições Afrontamento o $59 \mathrm{pp}$

Tinoco A, Matos A, Santos L, Póvoas L, Relvas JMRS, Lopes C, Barriga FJAS, Damas C (2002) A valorização do património geológico e mineiro do Lousal. Actas Congresso Internacional do Património Geológico e Mineiro. IGM/SEDPGYM/IPB, Beja

UNESCO (1996) Report of the expert meeting on geological and fossil sites held at the 30th International Geological Congress Beijing, China, 8-10 August 1996 http://whc.unesco.org/archive/1996/whc96-conf201-inf10e.pdf accessed 2 May 2013

UNESCO (1998) Non-formal and formal learning interactions: new directions for scientific and technological literacy. Connect UNESCO Int Sci Technol Environ Educ Newsl 1:1-2 